\title{
Refuge
}

Canada's Journal on Refugees

Revue canadienne sur les réfugiés

\section{Protection amid Chaos: The Creation of Property Rights in Palestinian Refugee Camps, by Nadya Hajj}

\section{Rex Brynen}

Volume 33, Number 2, 2017

URI: https://id.erudit.org/iderudit/1043069ar

DOI: https://doi.org/10.7202/1043069ar

See table of contents

Publisher(s)

Centre for Refugee Studies, York University

ISSN

0229-5113 (print)

1920-7336 (digital)

Explore this journal

Cite this review

Brynen, R. (2017). Review of [Protection amid Chaos: The Creation of Property Rights in Palestinian Refugee Camps, by Nadya Hajj]. Refuge, 33(2), 103-104. https://doi.org/10.7202/1043069ar 
racial discrimination. This chapter in the book moves from the Hong Kong material to take up Indochinese refugees and resettlement globally, arguing that the mythologizing narratives that instrumentalized generosity among white settler societies came to dominate popular understanding of these events. During this process, Hong Kong was a critical intermediary as a country of first asylum for peoples of Southeast Asia and helped to shape the global response to Southeast Asian refugees through screening, repatriation, and resettlement. Once again, decisions were made based on definitions of what constituted a "real refugee" as opposed to a less deserving migrant, decisions that ultimately played a gatekeeping role that restricted migration according to classification.

Laura Madokoro's book has used the history of Chinese migrants in Hong Kong to demonstrate the complexities as well as the continuities of movements of East Asian and South Asian peoples in the twentieth century. Starting with the Cold War contradictions of humanitarian construction of the "refugee" in post-1949 Hong Kong, and moving through the history of Asian exclusion and the ambivalent resettlement policies of white settler colonies through the 1970s, she is able to simultaneously tell a local and a global story. This monograph will have relevance for scholars and students of global refugees and migration, not only in historical perspective but also today.

Jamie Monson is professor of history and director of the African Studies Center at Michigan State University. The author can be reached atmonsonj@isp.msu.edu.

\section{Protection amid Chaos: The Creation of Property Rights in Palestinian Refugee Camps $\sim$ \\ Nadya Hajj \\ New York: Columbia University Press, 2016, pp. 214}

$\mathrm{B}$ ased on extensive fieldwork and interviews, this book outlines the complex nature of property rights in Palestinian refugee camps in Jordan and Lebanon. Particular attention is devoted to issues that have arisen in the reconstruction of Nahr al-Barid refugee camp, following the 2007 conflict there between the Lebanese Army and the Fateh al-Islam armed group. Hajj offers considerable insight into social and economic dynamics within Palestinian camps. She also makes a substantial contribution to our understanding of how informal institutions, local configurations of social and political power, and formal law and regulation interact to shape property ownership. Her study is particularly relevant to protracted refugee situations, but its value extends well beyond.

Most Palestinian refugees in Jordan are Jordanian citizens, with full legal rights. Hajj's analysis shows that a gradual synthesis has occurred between the initial post-1948 community-based system whereby property rights were recognized and enforced in the camps, and the formal Jordanian legal system. Since the Jordanian civil war (1970-1), the government has sought to expand state control and authority. The author might have more fully addressed the original ownership of refugee camp land: some camps were built on state land, while others stand on land that is nominally rented from Jordanian landowners. Some original landowners feel they have lost effective control over their former properties and have threatened to use the legal system to regain it. The Jordanian government has discouraged court challenges in order to maintain political stability, but it has sometimes suggested if the refugee issue was resolved, such claims of (re)ownership would indeed go forward.

In Lebanon, matters are more complex. Most Palestinian refugees are stateless, and Lebanese law prohibits refugees from owning property. The rise of Fateh and other Palestinian armed factions in the camps from the late 1960 s created a new dynamic of local power, one that largely displaced any limited authority exerted by the already weak Lebanese state. Customary systems were also increasingly supplanted by the quasi-hegemonic role of Fateh, and the growing role of formal camp committees. In many cases, later changes in local power structures then forced modification or renegotiation of these practices. In Nahr al-Barid, for example, Hajj shows how the Lebanese government pressed for greater control and authority as the United Nations Relief and Works Agency for Palestine Refugees in the Near East (UNRWA) undertook camp reconstruction.

As the author points out, very little has been written on the lived practices of refugee camp property rights in Palestine. In the late 1990s and 2000 s the World Bank and the Palestinian Authority partially examined how informal property rights in Palestinian refugee camps might affect redevelopment, repatriation, and reparations in a Middle East peace agreement. It is hardly surprising that the author does not appear to be aware of this, since (in view of its potential political sensitivity) none of their work was ever 
published. The issue of acquired rights was also prominent in UNRWA's development of participatory planning for its reconstruction of Jenin camp in the West Bank, which was partially destroyed by fighting between Palestinian militants and the Israeli Army in 2002. Indeed, aspects of the Jenin experience served as a model for Nahr al-Barid.

The bulk of Hajj's research and interviews in Lebanon focus on the north of the country. It would have been useful to have seen comparative attention to other camps where there have been less dramatic changes in local power structures, where Fateh was marginalized for a time after 1982, or camps that experienced considerable local insecurity, violence, and factionalization (notably in Ayn al-Hilwa camp). It might have also have been interesting for the book to have more deeply explored the differences between land ownership in Nahr al-Barid camp itself (the "Old Camp"), and the surrounding mixed areas into which the Palestinian refugee population has expanded over the years (the "New Camp"). In many cases, properties in the latter areas are "owned" by Lebanese lawyers or other intermediaries acting on behalf of one or more Palestinian families, thereby creating an informal workaround of Lebanese restrictions on refugee property ownership.

Although the book focuses primarily on adaptation of informal and formal institutions by refugees to maintain a workable system of property rights, host country policy is often more complex, nuanced, or even contradictory than accounts suggest. In Lebanon, for example, very different views of Nahr al-Barid reconstruction could be heard from Lebanese security officials on the one hand, and those in official Lebanese-Palestinian Dialogue Committee on the other. It is noteworthy that, despite a legacy of political tension over the refugee issue that dates to the Lebanese civil war (1975-6) and before, the Lebanese government formally committed to reconstruct Nahr al-Barid, even as the fighting was ongoing, distributing posters and pamphlets among displaced refugees that pledged, "Your departure is temporary, your return is certain, reconstruction is guaranteed."

Protection amid Chaos stands as a major contribution to the refugee literature. While there are aspects of the issue that one might have wished to see more fully addressed, this arises more from the importance and complexity of the topic, and the limits of available space, than to any shortcomings in the author's analysis. I strongly recommend this book.

Rex Brynen is professor of political science at McGill University. The author may be contacted at rex.brynen@mcgill.ca.

\section{Congolese Social Networks: Living on the Margins in Muizenberg, Cape Town \\ $\sim$}

Joy Owen

Lanham, MD: Lexington Books, 2015, p. 272

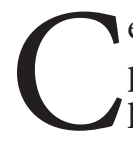
ette monographie par Joy Owen est captivante principalement pour deux raisons. En premier lieu, il sagit du premier ouvrage académique qui se concentre totalement aux Congolais de la ville du Cap (Afrique du Sud) comme une communauté transnational à part entière. Deuxièmement, l'auteur fait preuve de grande habileté comme chercheuse en cultures transnationales, mais aussi d'un niveau avancé de connaissance de son milieu de recherche (Muizenberg, au Cap) et de ses "sujets » de recherche (les Congolais). Ici, nous soulignons sa proximité avec ses sujets quelle nous narre fièrement à travers ses notes ethnographiques et surtout quand elle nous informe que la production de Congolese Social Networks «est une culmination de 15 mois de travail sur terrain de 6 ans, relations battues et maintenues à travers de distances nationales et internationales, et une recherche qui est partie d'un intérêt honnête d'une connaissance : un «autre»» (p. 68).

Louvrage est subdivisé en trois parties. La première contenant les trois premiers chapitres de l'ouvrage est introductoire au sujet majeur abordé dans la suite. Le premier chapitre traite brièvement de la République Démocratique du Congo (RDC) et de son histoire dans le contexte migratoire local et transnational. Dans cette partie, Owen revoit les aspects les plus importants des migrations de lépoque précoloniale à la colonisation Belge en passant par les années de travaux forcés dans le Congo du Rois Léopold II. Ensuite, elle passe à l'époque d'après la colonisation, en insistant sur les longues années du règne du Président Mobutu sous lesquelles émerge la fameuse «deuxième économie» basée sur les «circuits personnels» sur lesquels se fonde le discours de "article 15» souvent dit «débrouillez-vous». Concernant ce dernier, Owen explique que lépoque de Mobutu «a engendré une société souple, voulant circonvenir les normes sociales et les mœurs pour parvenir à survivre» (p. 26). Cette débrouillardise demeure au cœur de la survie socio-économique des Congolais partout où ils se retrouvent.

Le deuxième chapitre touche les complexités autour des lois migratoires en Afrique du Sud. Owen analyse le 